\title{
PROBLEMS OF PASSENGER AND FREIGHT TRAINS COMBINED TRAFFIC ON HIGH-SPEED RAILWAY LINES
}

\begin{abstract}
The article presents problems of combined traffic of passenger and freight trains on high-speed railway lines. It was established that one of the directions of ensuring the further growth of both freight and passenger transportation effectiveness is the increase of train speeds. Technological and operational parameters of the line under combined motion are considered and measures to increase the throughput capacity are proposed.
\end{abstract}

Keywords: passenger transportation, cargo transportation, high-speed railway lines, capacity, high-speed train

\section{Introduction}

Increasing the rail transport competitiveness in the transport services market be achieved may by reducing the transportation time and ensuring the regularity of the passengers and freight delivery. Reducing the passengers and goods time transportation is an urgent problem of all transport modes. On the railway transport, travel time reduction is possible by reducing the train's stoppings and increasing the running speed.

The transport attractive creation by conditions through the development of high-speed traffic will allow additional passenger traffic from aviation and road transport to railways, as well as increase the attractiveness the transit freight corridors in Ukraine.

On the railway transport, each "path" of train schedule makes it possible to provide high capacity of high-speed lines, which provides transportation of a considerable quantity of cargo and passengers, in comparison with other 
modes of transport. Therefore, the combined use of passenger and freight trains on high-speed rail lines to deliver high value-added freight will increase the level of competitiveness of rail transport.

The expediency of construction and increasing the efficiency of the of high-speed railway lines is increasingly found in scientific works. Paper (Barash, Momot, 2012) presents several scientific approaches to determining the expediency of introducing high-speed motion in Ukraine and proposes the research results. The Concept foresees (Zakon5.rada.gov.ua, 2014) the creation a of high-speed railways network in Ukraine to connect the Ukraine capital with major regions, as well as with countries in Western Europe and the CIS. Construction of high-speed railways in Europe has proved to be, generally, effective, but experience analysis suggests that the result is not always positive.

The overwhelming majority the railway networks throughout the world are based on a combined movement (Pyrgidis, Georgakopoulou, 2007; Pyrgidis, Christogiannis, 2012). On the one hand, this practice seems to achieve economies of scale, since freight and passenger traffic use the same rail infrastructure, on the other hand, problems arise for managing the rail system, as trains with different technical and operational characteristics run on one and the same the same way.

The development of high-speed railways led to a change in the passenger traffic structure (Clewlow, Sussman, Balakrishnan, 2014). Thus, part of the passenger traffic, which used aviation transport at small distances, began to use the less expensive railways while maintaining aviation over long distances. The paper (Chen, 2012) shows how high-speed trunks affect both the China national economy in general and urban and regional development in particular. For high-speed railways, the important task is to determine the time of trains departure. Therefore, when developing traffic schedules (Espinosa-Aranda et al., 2014) it is necessary to take into account the passengers requirements regarding the time of high-speed trains departure and the passenger trains movement schedule of other categories (suburban, urban trains). At the same time, attention is paid to the commercial use of bandwidth and the formation of a "fair price" in the equal conditions access to the general railways infrastructure (Myronenko, Matsiuk, Rodkevich, 2015). The interaction effectiveness of the transport market participants - infrastructure manager and rolling stock operators, carriers and cargo owners - may be determined by the actual demand for rail transport infrastructure. With the high-speed traffic organization, along with running speed, minimum train intervals are increased (Nikitin, Boltaev, Glybovskij, 2016), which can significantly affect the technological reliability of interaction between stations and adjacent sections (Matsiuk, 2017).

One of the main reasons for such a sharp increase of interest in high-speed freight trains is the large-scale plan of China to build new routes for the delivery its own products to European countries within the framework of the New Silk Road (Vedomosti.ru, 2017). Within the framework of this project, Ukraine is defined as a promising and important partner (Khanna, 2017). However, only Ukraine depends on successful implementation of new perspectives. 


\section{Formulation of the problem}

The world experience of the countries of Western Europe, Japan and China shows that the speed of $300-450 \mathrm{~km} / \mathrm{h}$ can be technically realized. However, the construction of high-speed lines and special rolling stock requires large investments, which is not always possible. In our case, as an alternative, one can consider the high-speed passenger traffic organization on lines with combined traffic of freight and passenger trains: up to $200-250 \mathrm{~km} / \mathrm{h}$ - after major repairs of the track and up to $300 \mathrm{~km} / \mathrm{h}$ - on reconstructed lines.

The question arises whether there are problems of passenger and freight combined traffic on the high-speed railway lines? The use of the same track for passenger and freight trains affects the operation and maintenance of the railway system as a whole. With a combined motion, there are technical aspects, economic and other problems.

The passenger trains characteristics are different from the characteristics of freight trains with parameters such as train weight, axle load, train length, train speed, daily traffic load, train braking distance, etc.

Let's consider in more detail the problems that arise when combined traffic of freight and passenger trains.

\section{Technical and investment aspects}

The limiting technical element of a complex railway devices regarding the level of train speeds is the upper structure of the track and the earth's canvas. Therefore, when designing a new high-speed line for combined traffic of passenger and freight trains, it is necessary to ensure a minimum curves radius in order to achieve a speed of over $200 \mathrm{~km} / \mathrm{h}$, a smooth and comfortable trip for passengers, and a minimum rail transport depreciation. To do this, you need to design the track so that the outer rail is usually raised above the inner rail level. Simply put, it is necessary to achieve a balance between the centripetal force of the train pushed out around the curve and the force of gravity pulling it inward at the speed with which the passenger train will take place at the station (Rail Turkey English, 2014).

By the introduction of high speed in Ukraine causes the need to solve new rather complicated problems:

- raising the technical level of railway infrastructure;

- production of high-speed rolling stock and various railway vehicles;

- creation of new automated systems and information technologies.

High-speed passenger traffic on the railways of Ukraine should connect cities and other settlements with a large population, with intense business activity, preferably attractive to tourists, with a reduction in the duration of passenger travel from 8-10 hours to $3-5$ hours, an increase in the number of seats in passenger cars by 1,5-2 times (from 36 to 54 and more seats) and reducing the needs of the passenger rolling stock.

For freight traffic the route should provide the shortest distance and the shortest time for the international transit cargo transportation. In the gravity area of the route 
should be concentrated enterprises that are shippers and consignees. The route should be with a minimum curves and minimum deviations, with a minimum intersection of water obstacles and boundaries of settlements. The route should be as much as possible within the strip of the existing railroad and, if possible, use existing electricity supply systems. This will increase the competitiveness of rail transport. The routes specialization of the future HSR lines by type of transportation (passenger, cargo), taking into account the above criteria, is shown in Figure 1.

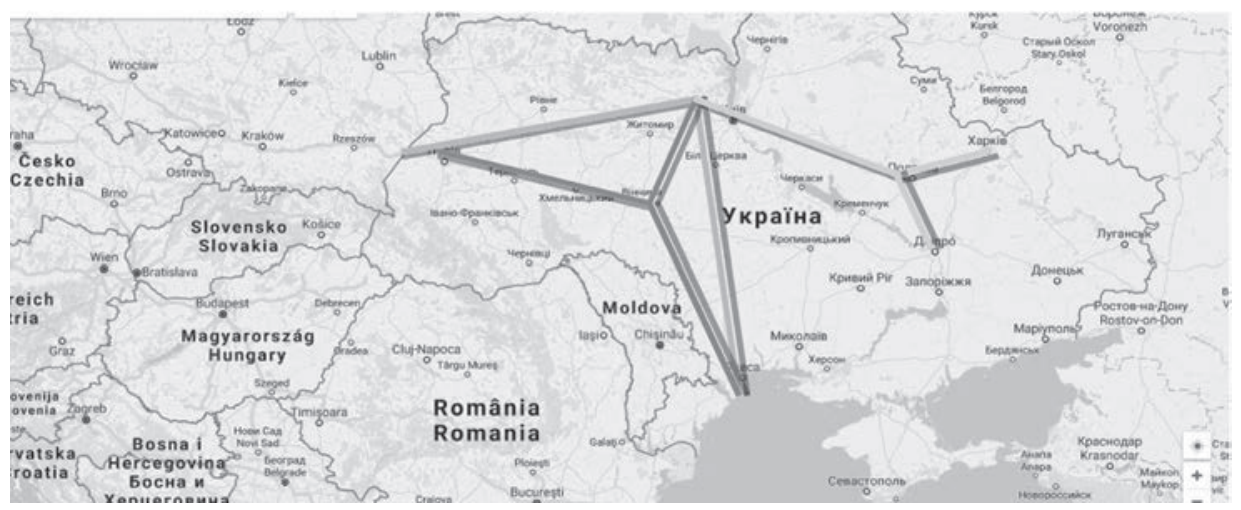

Figure 1. Possible specialization of routes

Source: (own elaboration)

The red color shows the mainly cargo transit direction for the cargo connecting the ports of "Big Odessa" with the border crossing of Mostyska-2 on the border with Poland, as well as the connecting line Kyiv - Zhmerynka / Vinnytsa (the exact location the connecting station of the connecting lines with a transit route can be established after more detailed surveys and feasibility studies).

The green color shows the alternative variant the combined passenger-cargo direction of Chornomorsk - Odessa - Kyiv - Lviv - Mostyska-2, without the link to Zhmerynka / Vinnytsa, and without the connecting line Kyiv - Zhmerynka / Vinnytsa. The advantages or disadvantages of this option, compared to what is shown in red, can also be determined only after more detailed searches and justifications that require funding.

The yellow lines show the perspective lines of the HSR, which form a predominantly passenger direction, linking the most populated cities and regions of Ukraine.

Mostly the passenger area is Kharkiv / Dnipro - Poltava - Kyiv - Lviv - Mostyska-2.

Preferably freight direction: Chornomorsk - Odessa - Zhmerynka / Vinnytsa Lviv - Mostyska-2.

Connecting line: Kiev - Zhmerynka / Vinnytsa.

On both directions, the train movement is combined, cargo and passenger.

The cost of construction of $1 \mathrm{~km}$ of two-track HSR with all the adjacent infrastructure (stations, energy supply substations, depots, etc.) is estimated 21 million US dollars (experience of China, Russia). Thus, the investment cost of the project will be approximately $\$ 22.5$ billion, including private $-75 \%$ or more. 
Again, it should be emphasized that, based on international experience, with such investment cost, the cost of pre-feasibility and feasibility studies will be approximately \$ 450 million, and no less than \$ 225 million. USA!

\section{Technical and technological aspects}

It is possible to increase speed as on existing lines when passing the combined flow of passenger and freight trains, as well as by the construction of specialized high-speed lines at the passage of only passenger trains. However, with the combined traffic of high-speed passenger trains, the conditions for the passage of ordinary passenger and freight trains due to additional stops that arise during overtakes deteriorate. As a result, the bandwidth of the line decreases.

Thus, the higher the speed of passenger trains on the line, the less it is possible to miss the cargo, and the operating costs of their movement are greater.

\section{Problems with bandwidth}

Under conditions of high-speed operation, there is a large difference in speed between a high-speed passenger train and a freight train. That may not be sufficiently safe and reliable due to significant disproportionate racing periods, polling stations. A shuttle train will cover the distance in just 10 minutes, and the freight train will take 45 minutes or more, perhaps in an hour depending on the mass, the maximum speed and the type of locomotive. Therefore, in order to run a freight train, the necessary interval between trains must be at least 40 minutes, while servicing passenger transport - perhaps more.

With the help of signaling, which allows you to lay the path of the graph every 3 minutes, this means that in this example, the laying of 1 freight train equals the passage of 13 passenger trains (Rail Turkey English, 2014)! Should the freight operator pay 13 trains for laying a passenger train to leave his train?

Therefore, in case of organization of combined traffic of passenger and freight trains, their movement must be ensured close to the values of running speeds in the range of $200-250 \mathrm{~km} / \mathrm{h}$.

\section{Conclusions}

As the above studies show, with combined traffic of freight and passenger trains there are problems associated with the establishment of train speeds, trains' mass set-up, selection of parameters of railway tracks, problems with throughput, etc.

It has been established that for the use of high-speed railway lines with combined trains, the speed of trains should be $200-250 \mathrm{~km} / \mathrm{h}$.

The introduction of high-speed lines in Ukraine will allow it to become one of the competitive countries on the European continent railway market. 


\section{References}

Barash, Y. and Momot, A. (2012), Analiz naukovih pidhodiv schodo obgruntuvannya ekonomichnoyi dotsilnosti budivnitstva v Ukrayini visokoshvidkisnih magistraley (Analysis of scientific approaches to the justification of economic feasibility of construction in Ukraine high-speed highways), Visnik ekonomiki transportu i promislovosti: zb. nauk.-prakt. statey, 40.

Chen, C. (2012), Reshaping Chinese space-economy through high-speed trains: opportunities and challenges, Journal of Transport Geography, 22.

Clewlow, R., Sussman, J. and Balakrishnan, H. (2014), The impact of high-speed rail and low-cost carriers on European air passenger traffic, Transport Policy, 33.

Espinosa-Aranda, J., García-Ródenas, R., Cadarso, L. and Marín, Á. (2014), Train Scheduling and Rolling Stock Assignment in High Speed Trains, Procedia - Social and Behavioral Sciences, 160.

Khanna, A. (2017), The new Silk Road is made of iron - and stretches from Scotland to Singapore. Available from http://www.paragkhanna.com/home/the-new-silk-road-is-made-of-iron -and-stretches-from-scotland-to-singapore [Accessed 15 March 2018].

Matsiuk, V. (2017), A study of the technological reliability of railway stations by an example of transit trains processing, Eastern-European Journal of Enterprise Technologies: Control processes, 1.

Myronenko, V., Matsiuk, V. and Rodkevich, O. (2015), Metodyka vyznachennya vartosti ta «spravedlyvoyi tsiny» dostupu do infrastruktury zaliznychnoho transportu zahal'noho korystuvannya (Methodology for determining the value and "fair price" of access to the infrastructure of general rail transport), Zaliznychnyy transport Ukrayiny, 2.

Nikitin, A., Boltaev, S. and Glybovskij, A. (2016), Osobennosti realizacii funkcij jelektricheskoj centralizacii dlja vysokoskorostnyh poezdov na linijah smeshannogo dvizhenija (Peculiarities of realizing electric centralization functions for high-speed trains on mixed-motion lines), Nauchno-tehnicheskij zhurnal «Izvestija Transsiba», 2.

Pyrgidis, C., Christogiannis, E. (2012), The Problems of the Presence of Passenger and Freight Trains on the Same Track, Procedia - Social and Behavioral Sciences, 48.

Pyrgidis, C., Georgakopoulou, A. (2007), Pure or mixed train exploitation? Basic perational principles and decision tools», $1^{\text {st }}$ International Congress "Competitiveness and of means of transport, perspectives for interposal transport", Chios, Greece, 10-12/5/07, Congress proceedings.

Rail Turkey English. (2014). Can high speed trains and freight services share same tracks?. Available from https://railturkey.org/2014/12/18/high-speed-and-freight-trains-on-same-line/ [Accessed 15 March 2018].

Vedomosti.ru. (2017), RZhD i kitajcy proektirujut gruzovoj poezd so skorost'ju $350 \mathrm{~km} / \mathrm{ch}$. (Russian Railways and the Chinese are designing a freight train at a speed of $350 \mathrm{~km} / \mathrm{h}$ ). Available from https://www.vedomosti.ru/business/news/2017/02/01/675754-rzhd-gruzovoi-poezd [Accessed 15 Mar.ch 2018].

Waters, W. (2017), China building high-speed freight trains - Lloyd's Loading List, Available from https://www.lloydsloadinglist.com/freight-directory/news/China-building-high-speedfreight-trains/65289.htm\#.Weym91u0PIU [Accessed 15 March 2018].

Zakon5.rada.gov.ua. (2014), On Approval of the Concept of the State Target Program for Implementation on the Railways of High-Speed Trains for Passenger Trains for 2005-2015 (№ 979-p) Available from http://zakon5.rada.gov.ua/laws/show/979-2004-\% D1\% 80 [Accessed 15 March 2018].

\section{Corresponding authors}

Viktor Myronenko can be contacted at: pupil7591@gmail.com Tetyana Hrushevska can be contacted at: gtm1520@gmail.com 